\title{
Measuring and weighing psychostasia in Q 6:37-38: Intertexts from the Old Testament
}

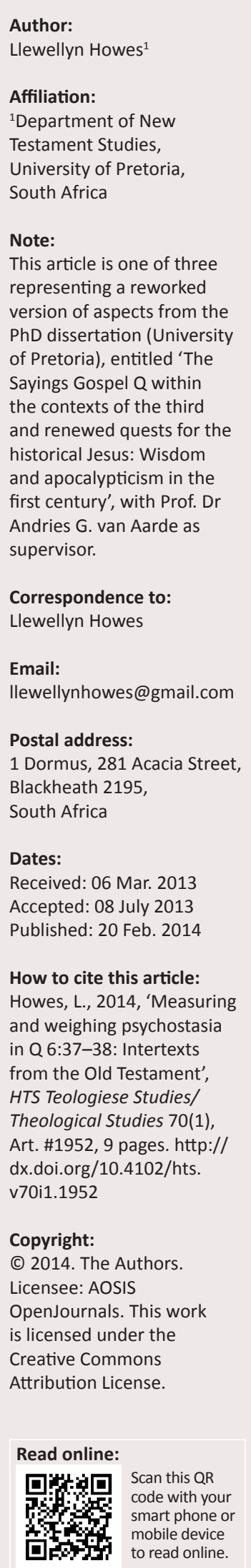

This article is the first of three on the relationship between the Sayings Gospel $Q$ and the ancient concept of 'psychostasia,' which is the ancient notion that a divine or supernatural figure weighed people's souls when judging them. The ultimate goal of all three articles is to enhance our understanding of $Q$ 6:37-38, as well as of the $Q$ document as a whole. In the current article, attention is focused on intertexts from the Old Testament, and the occurrences therein of the word 'measure' and the concept of 'psychostasia'. The implications of these results for our interpretation of Q 6:37-38 are briefly noted. A second (future) article will focus on intertexts in apocryphal and pseudepigraphical writings from Second Temple Judaism dealing with 'psychostasia'. A third study will ultimately spell out in more comprehensive detail the implications of the foregoing intertextual investigations on both our understanding of $Q$ 6:37-38 and our understanding of the Sayings Gospel $Q$ as a whole.

\section{Q 6:37-38: Sapiential, apocalyptic or judicial judgement?}

For reasons discussed elsewhere (see Howes 2012:234-244), $Q^{1}$ 6:37-38 is currently reconstructed as follows:

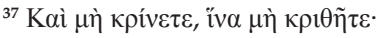

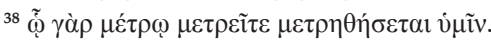

[ ${ }^{37}$ And do not judge, so that you are not judged;

${ }^{38}$ for with that measurement you measure with, it will be measured to you.]
}

Virtually all contemporary scholars view Q 6:37-38 as a piece of wisdom. Although some scholars question the sapiential nature of individual sayings in the inaugural sermon, ${ }^{2}$ they all admit to the obvious sapiential nature of the sermon as a whole (cf. Horsley 1999:88). A number of indicators clearly mark Q 6:37-38 as a wisdom text: (1) The inaugural sermon as a whole, including Q 6:3738, is introduced in Q 6:20 as a piece of wisdom (cf. Casey 2009:169-170; Howes 2012:190). (2) The inaugural sermon as a whole, including Q 6:37-38, corresponds formally, structurally and thematically best with the genre of wisdom (cf. Howes 2012:192-193; Van Aarde 1994:174; see Edwards 1976:61, 84-93; Kirk 1998:388-390, 396-397; Kloppenborg 1987:187-188). (3) Q 6:37-38 is argumentative and deductive in nature. (4) Three traditional and unmistakably sapiential small forms are used in Q 6:37-38, namely a prohibition or negative admonition, a motive clause and a maxim (cf. Edwards 1976:89; Kirk 1998:91; Kloppenborg 1987:180; Piper 1989:36-37; cf. also Ceresko 1999:35; Murphy 1981:4, 6; Winton 1990:28). (5) The maxim in verse 38 was a traditional wisdom saying of the time (cf. Mk 4:24; cf. Perdue 1986:10; Piper 1989:38). (6) Q 6:37-38 makes much use of parallelism (see Howes 2012:243-244). (7) As with other sapiential texts, Q 6:37-38 is concerned with the well-being of its hearers (cf. Crenshaw 2010:16). (8) As with other wisdom texts, Q 6:37-38 is aimed at the implementation of some ideal or praxis in daily existence (cf. Crenshaw 2010:16). (9) As with other wisdom literature, Q 6:37-38 substantiates its proposed wisdom by drawing upon our experience and understanding of (daily) human conduct. In this specific case, the 'measuring' of verse 38 calls to mind barter exchanges in the ancient market place (cf. Youngquist 2011:48). (10) As with other wisdom texts, the common sapiential schema of cause-and-effect is central to Q 6:37-38 (cf. Kloppenborg 1987:180, n. 45; Piper 1989:38).

Despite the great degree of certitude that this is a wisdom text, there may be some indications within the saying itself that Q 6:37-38 is also hinting at apocalyptic judgement: (1) The verbs

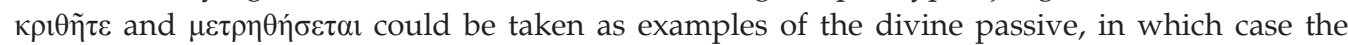
subject of both actions is God (cf. Kirk 1998:168; Robbins 1998:196). It should be noted, however, that although the divine passive was commonly used in apocalyptic and prophetic material, it was not exclusive to those writings. The divine passive was also used in wisdom literature (cf. e.g. Job 4:20; 14:5; Pr 11:31; 19:23; Ec 6:10; Q 11:2, 9; 12:2, 10, 31; [14:11]). (2) The fact that 


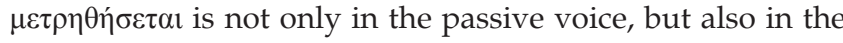
future tense, is perhaps suggestive of apocalyptic intent. (3) Edwards (1969:14) long ago discovered a possible propheticeschatological Gattung in the New Testament (cf. e.g. Mt 13:40; Rm 5:19; 1 Cor 15:22, 49; Q 11:30; 17:24, 26, 27, 30). This proposed Gattung is typically made up of two parts containing the same verb. In the first part, the verb is usually in the active voice, and refers to human activity. In the second part, the verb is usually in the passive voice, and refers to the eschatological judgement of God. Q 6:37-38 has all these features in common with Edwards' eschatological Gattung.

There are also some additional indicators from the literary context of $Q$ 6:37-38 that this sapiential saying could have had apocalyptic judgement in mind: (4) If $Q 6: 37-38$ is read in conjunction with the beatitudes in Q 6:21-23, an apocalyptic reading of the former text is suggested. Whereas the beatitudes (and perhaps $Q$ 6:35) could be taken as statements about apocalyptic reward, Q 6:37-38 could be taken as a statement about apocalyptic judgement. If this possible reading of Q 6:37-38 is accepted, it should be noted that the prohibition not

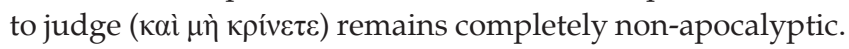
It is the motive clause (iv $\alpha \mu \eta \dot{\eta} \kappa \rho t \theta \tilde{\eta} \tau \varepsilon$ ) that could in this case be read in combination with the beatitudes, thereby possibly turning it into an apocalyptic argument aimed at buttressing the initial prohibition. (5) God is expressly mentioned in the preceding logion as the enactor of divine mercy (o $\pi \alpha \tau \eta$

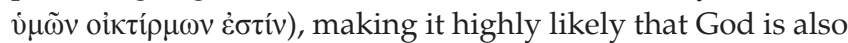
implied in verses 37-38 as the enactor of divine judgement (cf. e.g. m. Shab. ${ }^{3}$ 127b; 151b; t. Bab. Kam. ${ }^{4}$ 9:30; p. Bab. Kam. ${ }^{5}$ 8:10; cf. Sanders 1977:133-134). (6) If the motive clause in Q 6:37b refers to God's apocalyptic judgement, it is in perfect continuity with the announcement of God's apocalyptic judgement in the rest of Q. Kloppenborg's main redaction and is sometimes also referred to as the 'judgement layer'. One of the central themes of this layer is the announcement of apocalyptic judgement against a host of rivals, including 'this generation' (cf. esp. Q 7:31-35; Q 11:16, 29-32, 49-51; Q 13:28-29; Q 17:26-27, 30), Galilean towns (cf. esp. Q 10:13-15), sceptics (cf. esp. Q 11:14-15, 17-20), and the twelve tribes of Israel (cf. esp. Q 22:28, 30).

There is one last possibility for interpreting Q 6:37-38. Piper (1995) made an important contribution to our understanding of Q by noticing, within Q's aphoristic sayings, a thread of pessimism aimed at institutionalised violence and exploitation. More specifically, the institutionalised legal system was met with distrust, and courts were to be avoided at all costs (cf. e.g. Q 12:58-59; cf. Piper 1995:60; cf. also Horsley 1995:45). Piper (1995:62-63) finds evidence in Q that the $\mathrm{Q}$ people had not only a lack of confidence in the legal system, but also anxiety for authorities and suspicion over administrative procedures (see also Howes 2012:265-271). In general, there is more than enough reason to believe that $\mathrm{Q}$ fostered a gloomy attitude to the institutionalised judicial

3.Mishnah Shabbath.

4.Tosefta Baba Kamma.

5.Palestinian Talmud Baba Kamma. system, and that the $Q$ people had valid reasons for fearing not only court appearances, but also the authoritative figures which were in charge of such proceedings.

It is surely possible that this genuine concern lies behind the saying in Q 6:37-38. Such an appraisal is further suggested by the inaugural sermon, especially the examples of how to love one's enemies in Q 6:29-30. The actions described by Luke 6:29 and Matthew 5:39-41 ${ }^{6}$ require figures of authority

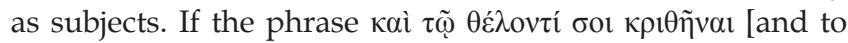
the person wanting to take you to court] in Matthew 5:40 is accepted as part of $Q$, then we have an explicit reference to judicial judgement, as opposed to apocalyptic or moral judgement, in the inaugural sermon. This Matthean phrase is the only other instance where the verb крív $[$ [judge] (of Q $6: 37)$ is repeated in the rest of the inaugural sermon. It is truly

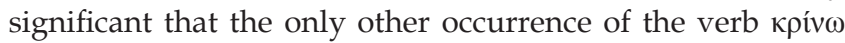
in the inaugural sermon denotes judicial judgement, and not moral or apocalyptic judgement - that is, of course, if this Matthean phrase was part of $Q$.

The idea that there was a deliberate connection between these two texts from the inaugural sermon might be supported by the use of the passive verb $\kappa \rho \imath \theta \tilde{\eta} \tau \varepsilon$ [you are judged] in Q 6:37b. The passive of кpív $\omega$ was mostly reserved for the judicial act of standing trial (cf. Louw \& Nida 1993a:555). If Q 6:37-38 is associated with the theme of juridical judgement, which appears both in Q 6:29-30 and throughout the Sayings Gospel as a whole, then this logion specifically exploits the existing fear of the institutionalised legal system to support its argument against judging other people. In such a case, the argument goes something like this: Do not act as judge and jury over other people, or you yourself will inevitably face the terrifying situation of being judged in a court of law by an authoritative figure.

Over and above the primary sapiential reading of the phrase iv $\alpha \mu$ iे $\kappa \rho \imath \theta \tilde{\eta} \tau \varepsilon$ [so that you are not judged] in Q 6:37b, it has thus far been suggested that this phrase could simultaneously have been hinting at apocalyptic and/or judicial applications. Perhaps the ancient notion of 'psychostasia' could assist in determining the legitimacy of this claim.

\section{The concept of 'psychostasia'}

'Psychostasia' is the academic term for the 'weighing-ofthe-soul' concept (cf. Brandon 1969:91). Put differently, 'psychostasia' is the umbrella term for the ancient notion that a divine or supernatural figure judged ordinary people through weighing their worth on scales. Although the 'soul' is most frequently associated with this concept in ancient literature, other items might also be weighed, like the 'heart' or the 'spirit'. Regardless of the exact item being measured or weighed, it was normally some or other symbol for a person's inner being (cf. Brandon 1969:91). This idea had its inception

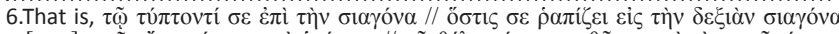

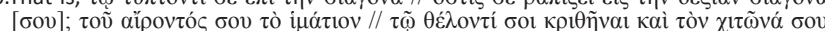

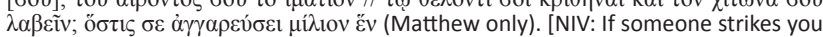
on the right cheek // If someone strikes you on one cheek; If someone wants to sue on the right cheek //If someone strikes you on one cheek; If someone wants to sue
you and take your tunic // If someone takes your cloak; If someone forces you to go one mile (Matthew only).] 
in Egyptian mythology. It is well known that the concept of psychostasia was an integral and widespread feature of Egyptian thought (cf. Pearson 1976:249; see Brandon 1969:91-99, esp. 99). Yet, the earliest Egyptian texts about the afterlife, written during the Old Kingdom period (24252300 BCE) do not utter a single word on psychostasia (see Brandon 1969:94-96). In those texts, post-mortem judgement is described in terms of symbolism and imagery taken from the earthly courtroom.

It is only during the First Intermediate period (2200-2050 $\mathrm{BCE}$ ), in the ancient Egyptian writing Instruction for King Merikarē, that a new element is added to the traditional imagery of a legal courtroom (cf. Brandon 1969:96). According to this text, the court proceedings would include the act of placing the good and bad deeds of the individual being judged in two respective heaps. This was done so that the deeds in each heap could be accurately measured. The fate of one's judgement would then depend on which heap contained more deeds, the good heap or the bad heap. That this slight divergence occurred in an Egyptian wisdom text might be somewhat significant. Brandon (1969:96) argues that this new addition to court proceedings was introduced in Egyptian myths about the afterlife because people generally did not trust the earthly justice system (see also Garnsey 1970; Piper 1995; cf. further Horsley 1995:45, 1996:120). Accordingly, this act of measuring good deeds against bad deeds ensured that the imagined legal proceedings would be objective and impartial. People were not at the mercy of the supernatural judge and his potential misgivings, preconceptions and partiality. Rather, their own deeds and behaviour determined their ultimate post-mortem fate.

The idea of 'weighing' first appeared in the Middle Kingdom period (2160-1580 BCE) in a series of manuscripts known as the Coffin Texts (cf. Brandon 1969:96-97). In post-mortem judgement scenes, mention is made in passing of balances, scales and weights (cf. Egyptian Coffin Texts, Spells 44, 335, 452). It is only during the New Kingdom period (1580-1090 $\mathrm{BCE}$ ) that the concept of psychostasia became full-blown in Egyptian mythology. The Egyptian Book of the Dead (125) describes the final judgement as an act of weighing the hearts of the dead against Maāt on a pair of scales (cf. Pinch 2004:2728, 93, 160, 210; Wink 2002:178). For Egyptians, the heart was more than just a vital organ. It was a cognisant entity that acted on its own, sometimes even against its owner. Some described the human heart as a little god that lived inside human beings (cf. Pinch 2004:59, 64). The heart contained a person's memory and intelligence, which is why it could act as a record of his or her life on earth (cf. Broyles 2006:31). More importantly, the heart symbolised the entirety of an individual's moral centre and censor (cf. Brandon 1969:92). In Egyptian mythology, the goddess Maāt, who personified Egyptian ethics and cosmology, was the daughter of the sun god Rē (cf. Pinch 2004:159). She represented the Egyptian idea of cosmic and social order, although the idea of cosmic order was ultimately personified by Rē himself. In her distinctive role as representation of social order, Maāt was viewed as the embodiment of 'truth', 'justice' and 'righteousness' (cf.
Brandon 1969:92). The Egyptian word maāt could literally mean 'truth'. 'justice', 'righteousness', 'balance', 'cosmic law' or 'order' (cf. Pinch 2004:159). In essence, Maāt (as well as maāt with a small letter) symbolised a criterion, benchmark or standard by which a person's character and conduct in this world could be measured (cf. Brandon 1969:92; Pinch 2004:159).

Thus, the final eschatological judgement was seen as a process of measuring and weighing a person's moral worth. From the New Kingdom period onwards, the concept of psychostasia gradually started replacing the idea that postmortem judgement was a judicial process comparable to an earthly courtroom (cf. Brandon 1969:98-99). According to Brandon (1969:98-99), this shift in emphasis is probably due to a growing need amongst Egyptians to emphasise the impartiality of eschatological judgement. It is important to note, however, that the two different symbols of eschatological judgement were never mutually exclusive. To the contrary, they occasionally existed side by side in not only the same manuscripts (like the Book of the Dead), but also the same passages (like the Instruction for King Merikare and the Papyrus of Ani 125).

The idea of psychostasia spread from Egypt to many other peoples and religions of the time (cf. Brandon 1969:99). Early Greek literature made regular use of the expression 'weighing of the souls' to describe judgement (cf. Wink 2002:178). In the Iliad (22:179), for example, Zeus is described as weighing the respective fates of Achilles and Hector as they fight against the Trojans (see Morrison 1997:276-296). In this scene, there are two noteworthy exceptions to the Egyptian understanding of psychostasia. Firstly, it were not the hearts (or moral worth) of the Greek heroes that were weighed, but their individual fates. Secondly, the Egyptian post-mortem judgement is replaced here by a Greek notion of pre-mortem judgement. Hence, this depiction of psychostasia concerns itself not with the eschatological judgement of the dead, but with the destiny of the living in this world. This attests to the tendency in ancient literature to not only adopt the Egyptian notion of psychostasia, but to also adapt it to their own particular needs. Thus, it would seem as though the symbolism of psychostasia (including the concepts of weighing, measuring, balances and scales) was easily taken over by others, but that the exact application of that symbolism (including the time and nature of judgement, as well as type of items being weighed) was modified to fit existing ideas of divine and/or supernatural judgement. This process of selective borrowing assured the successful assimilation of the psychostasia concept by many other peoples and religions.

Despite such varied application, the purpose of the weighing action remains the same in ancient literature: It was an impartial means by which some or other divine or supernatural figure determined how people should be judged (cf. Brandon 1969:99). Similarly, in all ancient versions of psychostasia, the symbolism finds expression in one of two ways. Either a representation of the individual under 
examination is weighed (sometimes - but not always against something else), or a person's good and bad deeds are weighed or measured against each other. A more precise phenomenological description of the concept of psychostasia in the history or different religions remains outside the scope of this article. Suffice it to say however, that this concept became very widespread in the ancient world and that it was commonplace in many cultures and religions by the turn of the millennium. As such, it later became common practice in many religions, including Islam, Zoroastrianism, Hinduism, Buddhism and medieval Christianity, to describe impartial, post-mortem and divine judgement in terms of the imagery of psychostasia (see Brandon 1969:109-110).

A crucial question for our intentions is whether or not this concept of psychostasia was a recognised and recognisable feature of Second Temple Judaism. Our investigation begins with the Old Testament. It is to this question that we now turn.

\section{The most important intertext for Q 6:37-38}

Leviticus 19 is indisputably the most important intertext for the inaugural sermon as a whole (see Allison 2000:29-38). Q 6:36 is mirrored by Leviticus 19:2. The second-person

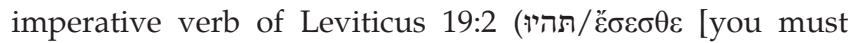
be]) is replicated by a second-person imperative verb in

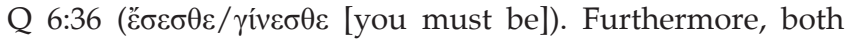
texts justify their imperatives with an imitatio Dei rationality. Yet, the Old Testament text is significantly altered by the

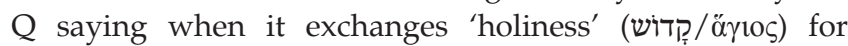

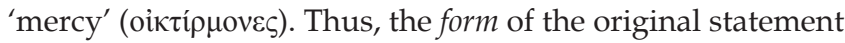
(second-person imperative plus imitatio Dei justification) is kept intact, but the meaning is radically renovated with

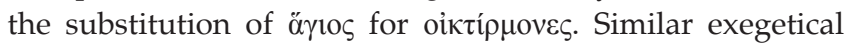
activities appear in rabbinical commentaries on Leviticus (cf. e.g. Lev. Rab. ${ }^{7}$ 308; b. Shab. ${ }^{8}$ 133b). Like Q 6:36, these rabbinical writings also substitute holiness for another virtue. Q 6:36 is an example of Q's Jesus reconstructing established Mosaic Law. Q's Jesus deliberately trades holiness for mercy (cf. Borg 1984:128). This trade-off is in continuity with the woes against the Pharisees and scribes (cf. esp. Q 11:42, 46b).

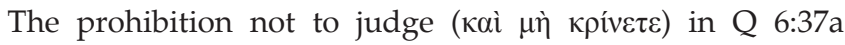
antithetically contradicts the commandment in Leviticus

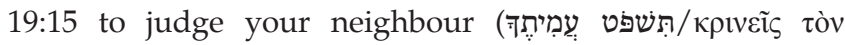
$\pi \lambda \eta \sigma i ́ o v \sigma o v)$. In Leviticus, the syntactical object of the judging act is one's neighbour. This object is deliberately removed from the $\mathrm{Q}$ text. The removal of the syntactical object of judgement in $\mathrm{Q}$ is an indication that verse 37 should be read in combination with the admonition to love one's enemies in Q 6:27. In other words, the prohibition against judgement does not only have family members, loved ones or friends in mind, but all people happening to cross one's path, including enemies. Just as with the instruction to be merciful, Q 6:37

7.Midrash Leviticus Rabbah.

8.Babylonian Talmud Shabbath. provocatively rewrites and reapplies conventional Mosaic Law. In the current case, however, the exact opposite of the Torah tradition is commanded. Hence, Q's Jesus advocates the following: 'Regardless of what Leviticus teaches, you must not judge other people, not even enemies!'

The reconstruction and modification of Leviticus 19 is a trademark tendency of the entire inaugural sermon (see Allison 2000:33-34). This tendency was not altogether unusual in ancient Jewish tradition (see Allison 2000:34-37). Q 6:37 adds the qualification 'so that you are not judged'

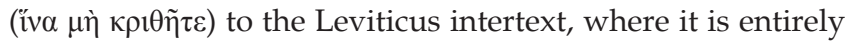
absent. The popularity and familiarity of Leviticus 19 in 1st century Judaism necessarily indicates that Jewish audiences would have picked up on the relationship between the inaugural sermon and this favoured Old Testament text (see Allison 2000:37-38). This applies not only to the general connection between these two texts, but also to the more subtle nuances and allusions to Leviticus 19 beneath the surface of the inaugural sermon.

Q supports the latter qualification by cleverly drawing upon and reapplying an entirely separate commandment in Leviticus (19:35-37). The latter text is a commandment not to be dishonest in day-to-day dealings, expressed by means of a negative admonition not to use fraudulent measuring implements and a positive admonition to use measuring implements that are accurate. A literal translation of the Masoretic Text [MT] is quite revealing for our purposes:

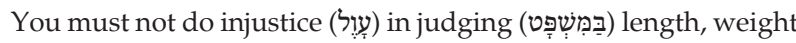

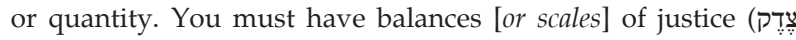
מאוְנוּי

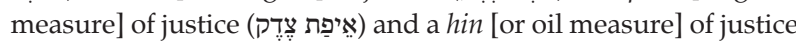
(וְהָיו צֶדֶק).

There are three Hebrew words in the Leviticus text that occur within the semantic field of the concept 'judgement'. The first (עוכ) denotes the type of injustice or wrongdoing that would typically be carried out by an evildoer or criminal (cf. Bosman, Oosting \& Postma 2009; Holladay 1971:267).

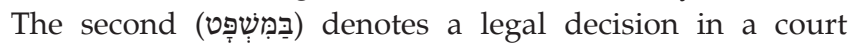
case, lawsuit or arbitration (cf. Bosman et al. 2009; Holladay 1971:221). The third (צֶדָק is repeated four times, and denotes that which is just and (legally) right (cf. Bosman et al. 2009; Holladay 1971:303).

In Leviticus 19:35-36, these words are used figuratively to connote unfair and dishonest dealings when goods are being sold or bartered. Hence the New International Version's (NIV) paraphrase of Leviticus 19:35-36: 'Do not use dishonest standards when measuring length, weight or quantity. Use honest scales and honest weights, an honest ephah and an honest hin.' The Septuagint did not translate the denotations of judgement and justice away:

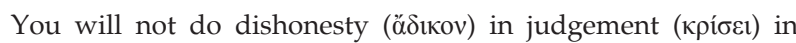

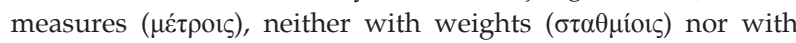

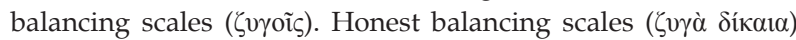

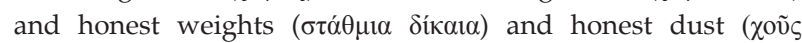

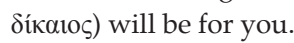


As with the Masoretic text, the Septuagint's (LXX) translation uses the concept of judgement or justice figuratively to connote unfair and dishonest dealings when goods are sold or bartered.

The individual(s) responsible for Q 6:38 obviously noticed the references to judgement in the original Masoretic and/ or Septuagint text(s) of Leviticus 19:35-36. These references to the concept of 'judgement' in a text that deals with the idea of 'measuring honestly' enabled Q's Jesus to link the admonition against judging others with a normal maxim about measurements. The saying in Q 6:37-38 has two crucial words in common with the Septuagint's version of Leviticus

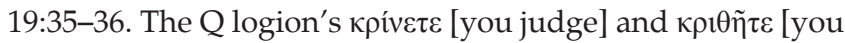
are judged] parallel the Septuagint's крíбє1 [judgement]. Also,

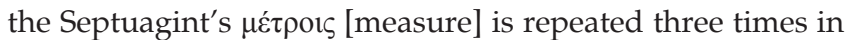
Q 6:38 with the phrase $\tilde{\omega} \mu \varepsilon \dot{\tau} \rho \varphi \mu \varepsilon \tau \rho \varepsilon \tau \tau \varepsilon \mu \varepsilon \tau \rho \eta \theta \dot{\sigma \varepsilon} \tau \alpha$ [the measurement you measure with, it will be measured]. The link between Q 6:37-38 and Leviticus 19:15, 35-36 is quite ingenious, and culminates in a total revision and inversion of the original Mosaic commandments.

\section{Psychostasia in wisdom literature}

The Torah commandment of Leviticus 19:35-36 was incorporated into the common wisdom of Israel. Proverbs 11:1 states: 'The Lord abhors dishonest scales, but accurate weights are his delight' (NIV). Proverbs 20:23 simply repeats the same sentiment: 'The Lord detests differing weights, and dishonest scales do not please him' (NIV). A third Proverb (16:11) reiterates the same basic principle: 'Honest scales and balances are from the Lord; all the weights in the bag are of his making' (NIV). The interesting aspect of this third saying is that it occurs in the midst of five sayings that deal with the king of Israel in particular. Proverbs 16:10, which immediately precedes the wisdom saying just quoted, states: 'A divine decision (קְָסָט) is upon the king's lips; in judgement

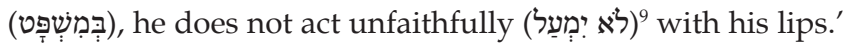
The noun קְְִ denotes specifically a decision or divination made with God's assistance through the casting of lots (cf. Holladay 1971:320). As in Leviticus 19:35-37, the word

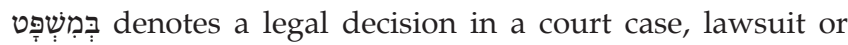
arbitration (cf. Bosman et al. 2009; Holladay 1971:221). When the two legs of this parallelism are taken together, the 'divine decision' of the first leg signifies a legal decision made with God's help. It follows that this wisdom saying has the king's role as legal judge specifically in mind. Hence, the wisdom saying in verse 11, about just weights and balances, follows upon another wisdom saying about judicial judgement.

It seems as though $\mathrm{Q}$ was not the first ancient writing to connect the commandment in Leviticus about measuring instruments with the concept of judgement. This connection was already part of Israel's wisdom tradition. The Septuagint did not translate the references to legal judgement away, preferring to keep both the reference to the 'king' ( $\beta \alpha \sigma i \lambda \varepsilon \dot{\varepsilon} \omega \varsigma)$ and the reference to a 'divine decision' ( $\mu \alpha v \tau \varepsilon i ̃ o v)$. Like Q

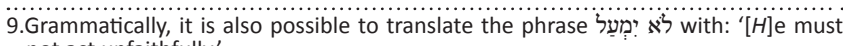
not act unfaithfully.'
6:37, the Septuagint's translation of Proverbs 16:10 employs the verb крíбєı when referring to 'judgement'. In both the Masoretic text and the Septuagint's translation of Proverbs 16:10-11, measuring instruments, like balancing scales and weights, are linked to legal judgement.

Earlier on in the same chapter, Proverbs (16:2) also makes mention of the measuring act, only this time it is not the king who acts as the subject of the action, but God: 'All a man's ways seem innocent to him, but motives (דוֹחוֹת) are weighed

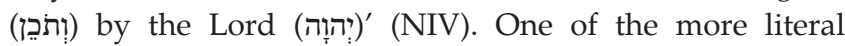
meanings of the Hebrew word translated here as 'motives' (רוּחוּת) is 'spirit' (cf. Bosman et al. 2009; Holladay 1971:334335), which is how the King James Version translated the word. This lexical meaning denotes the essence of what it means to be human. In at least this respect, the Hebrew noun רוּ רוּ is not conceptually dissimilar to the Platonic 'soul'

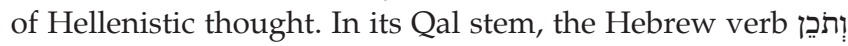
literally means to 'examine' (cf. Holladay 1971:390) or to 'test' (cf. Bosman et al. 2009). However, the Pi'el and Pu'al stems of תכן mean to 'measure' or 'weigh' something. This more than suggests that the Qal stem connoted 'examination' by means of 'measuring', 'weighing' or 'counting' something. In light of all this, Proverbs 16:2 could just as well be paraphrased as such: 'All a person's ways seem innocent to him [or her], but his [or her] spirit is examined when it is weighed by the Lord.'

תכן In all of the Old Testament, the Qal stem of the verb ('measure' or 'weigh') occurs only in two other texts, both of which are from Proverbs (cf. Pr 21:2; 24:12). In all three texts, it appears in the participle and in contexts where God is the implied or stated subject (cf. Bosman et al. 2009; Holladay 1971:390). The two other occurrences of this verb take the noun 'heart' or 'inner being' as object, thereby supporting the likelihood that רוּ should in Proverbs 16:2 be translated as 'spirit' (or even 'inner being'). The reason for 'weighing' a person's 'spirit' is not overtly mentioned in Proverbs 16:2, but the immediate context surely suggests that it has everything to do with that person's fate, both in this world, and in the one to come. In verse 2, the word 7i ('innocent' or 'pure') implies that a person's ways are sometimes not innocent, and therefore worthy of judgement. Verse 3 argues that God is in control of a person's destiny in this world. If verses 2 and 3 are read together, they suggest that a person's destiny in this world is determined by God's act of measuring the weight of that person's deeds (cf. Brandon 1969:99).

With the phrase 'day of disaster' (לְיוֹסָרָָה), verse 4, on the other hand, correlates God's act of weighing a person's deeds with the apocalyptic event that will inaugurate the world to come. Thus, Proverbs 16:2-4 symbolically describes the judging act of God as a procedure of weighing people's deeds. This judging act occurs not only at the final apocalyptic event, but also within this lifetime, where it is implemented indirectly by God via the inevitable consequences of unacceptable behaviour. This latter understanding of God's involvement in people's lives formed the basis of traditional wisdom as it is particularly developed by the book of Proverbs. It is also 
the crux of what is criticised by both Job and Ecclesiastes, although Job (42:7-17) might be understood as ultimately reaffirming this sapiential schema. The Septuagint left out verse 2 in its translation of Proverbs 16.

The other two proverbs where the verb תכן ('measure' or 'weigh') appears in its Qal stem are remarkably similar to Proverbs 16:2, and only seem to affirm the results above. Proverbs 21:2 states: 'All a man's ways seem right to him, but the Lord weighs the heart' (NIV). In the original Hebrew text, there are only three small differences between Proverbs 16:2 and Proverbs 21:2: (1) The latter text changes the

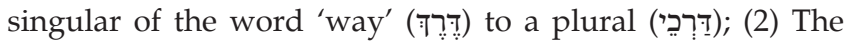
word 'pure' or 'innocent' (गI) is exchanged in the latter text for the word 'smooth' or 'right' (יָָָרָ); (3) As we have seen, the latter text prefers the word 'heart' (לִּּוֹ instead of 'spirit' (רוֹח). In all other respects, the two texts are exact copies of one another. Like the Jewish word 'spirit,' the word 'heart' also symbolised the essence of what it means to be human. Verse 1 of Proverbs 21 mentions the king, and states that even his heart is in God's hands. Thus, although the king, as we saw, weighs the hearts of others, and determines their destinies, God weighs his heart, and ultimately determines his destiny. The focus of Proverbs 21:1-8 is on this world, not on apocalyptic judgement. This is especially obvious in verse 5 , where the reward is monetary profit in this world, and the punishment is material poverty. For some reason or another, the Septuagint changed the verb 'weigh' in verse 2 to 'guide'

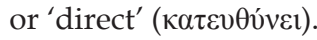

The last text of this nature, Proverbs 24:11-12, advises the wise to direct others in the ways of righteousness, in order to save them from apocalyptic death and slaughter. It is in this context that the following rhetorical question is asked of the wise: 'If you say, "But we knew nothing about this", does not he who weighs the heart perceive it?' (NIV). That Proverbs 24:11-12 has the apocalyptic event in mind is not

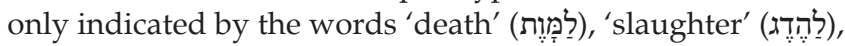
and 'life' or 'soul' (נַפְּשְָׁ), but also by the future tense and general effect of the rhetorical question at the end of verse 12: 'Will he not repay each person according to what he has done?' (NIV). Although God is not overtly mentioned as the subject of the weighing action, there should be no doubt that God is the intended subject. As in the previous text, the Septuagint had exchanged the verb 'weigh' for another verb,

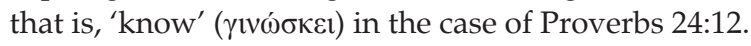

At any rate, there are three occurrences in the Masoretic text of Proverbs (16:2; 21:2 \& 24:12) that symbolically link God's judgement of people's deeds with the act of weighing their inner beings, which is either expressed as their 'spirits', 'hearts', or 'souls'. Proverbs 21:2 focuses on God's causal, this-worldly judgement, whilst Proverbs 24:12 focuses on God's apocalyptic, other-worldly judgement. Proverbs 16:2 elaborates on both. This indicates that these two types of judgement were neither contradictory nor mutually exclusive in contemporary Jewish thought. It also indicates that the symbolism of weighing someone's inner being was already an obvious metaphor for God's judgement when these proverbs were conceived.
Another wisdom text that deals with this theme is Job 31, where the protagonist is in the midst of defending himself and his own blamelessness against his friends. In verse 2 Job says that man's lot is determined by God. Verse 3 carries this forward by stating that God effects ruin for the wicked and disaster for those who transgress. In verse 4 Job admits that God sees his actions and counts his every step. In sum, Job argues that God determines the fate of each man on earth by counting his righteous and sinful deeds and by then rewarding or punishing him accordingly (cf. Brandon 1969:99). In light of this, Job laments in verses 5-8 that, if he had transgressed in any way whatsoever, then others should be judged and punished just as harshly. In the midst of this lamentation (v. 6), Job makes the following assertion: 'Let God

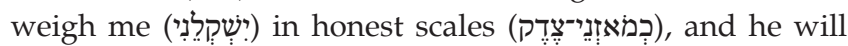
know that I am blameless' (NIV). Job 31:6 clearly associates the images of being 'weighed' and of 'honest scales' with God's this-worldly judgement (cf. Brandon 1969:100).

\section{Psychostasia in prophetic and apocalyptic literature}

It should be noted that the prophetic tradition also reproduces the commandment of Leviticus 19:35-36. Ezekiel makes use of this commandment as part of his efforts to reorganise the Jewish cult after the Babylonian exile. The Leviticus mandate appears in Ezekiel 45:10, which is part of a whole passage about standardising the types of produce and measurements to be used during cultic sacrifices (cf. also Am 8:4-6; Mi 6:11). In verses 11-12, Ezekiel spells out in no uncertain terms, just how precise, accurate and consistent these measuring instruments are to be from now on. The intention behind this development was to protect the poor against exploitation by the cultic and regal leaders of Israel (cf. esp. Ezk 45:8-9). In this sense, the Ezekiel text is an attempt to incorporate the Leviticus command as part of a brand new piece of legislation. What is missing for our purposes however, is a connection between correct measurements and the act of (judicial) judging. Although not particularly useful for illuminating $Q$ 6:38, this prophetic application of the Leviticus text to a postexilic situation does attest to the popularity and prevalence of the commandment in Leviticus 19:35-36. This directive occurs in all three of the Tanakh's major segments, namely the Torah (Dt 19:35-36; 25:14-16; Lv 19:35-37), the Nevi'im (Pr 11:1; 16:10-11; 20:10, 23), and the Ketuvim (Ezk 45:8-9; Am 8:4-6; Mi 6:11).

The apocalyptic book Daniel (5:1-31) describes a scene where a human hand appeared out of nowhere - in the midst of a royal banquet - and wrote four Aramaic words on the palace walls. The king, Belshazzar, summoned Daniel to interpret the writing. The four words were 'minay' (מְנָּא)

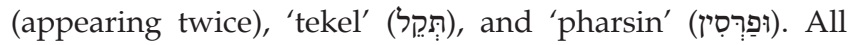
three Aramaic words were units for measuring weight (cf. Bosman et al. 2009). The first unit (מְנֵֵ) was usually used to measure the weight of precious metals, like gold and silver (cf. Holladay 1971:412). Daniel's interpretation of this word was that God had counted or weighed (بְ⿱乛龰) Belshazzar's kingdom and had brought it to an end. The second unit 
(תְתקָל Was also used to measure precious metals and luxury items (cf. e.g. Gn 24:22; Ex 30:23). Daniel's explanation of

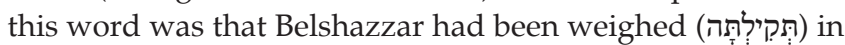

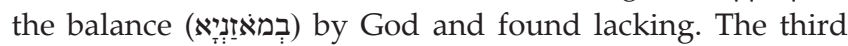
unit (וּפַרְִין constituted half a 'minay', and/or half a 'tekel' (cf. Bosman et al. 2009; Holladay 1971:418). Through clever

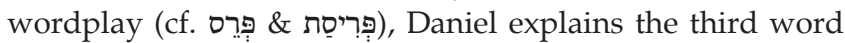
as meaning that Belshazzar's kingdom was divided and was given to the Medes and the Persians. Although the word 'judgement' occurs nowhere in this pericope God is indeed portrayed as judging Belshazzar and his reign (cf. esp. Dn 5:22-23). In Daniel's interpretation of the writings on the wall, measurements, balancing scales and weights are used to symbolise God's judgement of Belshazzar (cf. Brandon 1969:100).

The fulfilment of the prophecy that God will judge Belshazzar is accomplished that same night already, when Belshazzar is killed and his kingdom is taken over by Darius the Median (cf. Dn 5:30-31). In its literary context, this narrative is not an example of post-mortem, other-worldly judgement, seeing as the judgement is exacted upon a single individual within the confines of history (cf. Brandon 1969:100). However, the apocalyptic nature of the book as an entity, as well as its apocalyptic application to the situation in Palestine after Alexander the Great, suggests that this passage could also be interpreted as a reference to post-mortem, other-worldly judgement. If this passage is viewed together with Daniel's visions in chapters 7-12, the death of the king symbolises the death of all the wicked at the apocalyptic end.

Regardless of how we interpret Daniel 5:1-31, the king's judge in this pericope is God. Our examination of Proverbs 16:10-11 revealed that measurements of weight and balancing scales were symbolically linked to acts of juridical judgement by the king of Israel. In the current text, balancing scales and units of measurement are used to symbolise God's judgement of a foreign king. In this way, Daniel 5:1-31 is very similar in meaning to Proverbs 21:1-2. Thus, measurements and balancing scales came to symbolise both human and divine judgement. Although these references to units of measurement and balancing scales are translated away by the Old Greek version of the Septuagint, they are picked up again by the Theodotion version.

The idea that there was a connection between human and divine judgement was not an alien or inconceivable concept in ancient Jewish thought. References to God's heavenly council or court are scattered throughout the Old Testament. In ancient literature, heavenly courtroom scenes and psychostasia imagery often appeared together, as complementary depictions of post-mortem judgement (cf. Brandon 1969:96); descriptions of the one commonly elicited connotations and images of the other. ${ }^{10}$ A number of Old Testament texts liken God's heavenly court to human courts.

10.This linkage is expressed much clearer in Jewish literature from the Second Temple period than in the Old Testament. As such, the full worth of what follows wil only become apparent in the next article on psychostasia. Nevertheless, given the regular linkage between psychostasia and heavenly courts, the latter remain moderately applicable to the current investigation.
Not only is the heavenly court itself described with images and symbols of human courts, but the court proceedings are similar to those of earthly courts. Often, those partaking in the proceedings of the heavenly court use legal terminology.

1 Kings 22:19-22 paints a vivid picture of God on his throne, surrounded by the host of heaven. Job 1:6 has the sons of

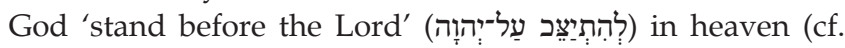

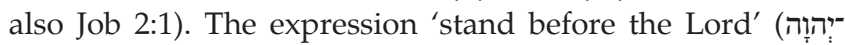
has legal connotations and specifically calls to mind someone appearing before a judge. The Septuagint retained this associative meaning, and even enhanced it,

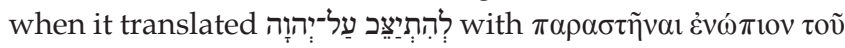
кupíov. 'Stand before' is one of the translation possibilities of $\pi \alpha \rho \alpha \sigma \tau \tilde{\eta} v \alpha 1$, but there are a number of alternative possibilities (cf. Newman 1993). The Septuagint clears up this confusion by adding the preposition $\dot{\varepsilon} v \omega \dot{\pi} \pi$ เov after $\pi \alpha \rho \alpha \sigma \tau \tilde{\eta} v \alpha$. This preposition literally means 'before' or 'in front of', but is often associated with the act of standing before someone in judgement (cf. Newman 1993). Moreover, one of the semantic meanings for $\pi \alpha \rho \alpha \sigma \tau \tilde{\eta} v \alpha \mathrm{t}$ is 'to hand over', and could literally mean 'to deliver a person into the control of someone else, involving [...] the handing over of a presumably guilty person for punishment by authorities ...' (Louw \& Nida 1993a:485, 1993b:189). Another possible meaning of $\pi \alpha \rho \alpha \sigma \tau \tilde{\eta} v \alpha r$ is to 'show to be true', denoting specifically the act of providing evidence in order to reveal the truth (cf. Louw \& Nida 1993a:673, 1993b:189). The setting of Job 1:6 in heaven and the combination of $\pi \alpha \rho \alpha \sigma \tau \tilde{\nu} v \alpha$ with $\dot{\varepsilon} v \omega$ itov leave a clear image - difficult to overlook - of an accused standing before a judge during a courtroom trial. In this (legal) case, God is

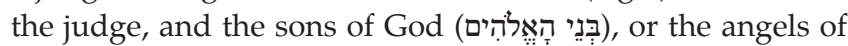

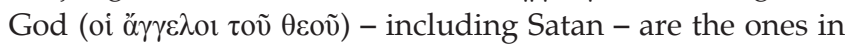
the dock.

Daniel 7:1-28 is one of the best examples in the Old Testament of a heavenly court being described with the imagery of human courts. Above all else, this pericope describes Daniel's vision about God's apocalyptic judgement. Verses 9-10 describe the preparation of the heavenly courtroom in anticipation of the commencement of unspecified legal proceedings. This preparation included the placement of thrones, the assembling of numerous attendees, and the moment when God - referred to here as the Ancient of Days - took his seat (cf. Wink 2002:52). Although the vocabulary of the current text differs from that of Job 1:6, the attendees

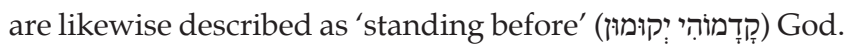
The Septuagint uses the same verb ( $\pi \alpha \rho \varepsilon \iota \sigma \tau \eta ் \kappa \varepsilon 1 \sigma \alpha v)$ as in Job $6: 1$, but this time it appears without the preposition $\dot{\varepsilon} v \omega \dot{\pi} \pi$ เov.

Then follows the phrase דינִא יְב. Tִינְאט) The noun used here can denote either 'judgement' or 'court' (cf. Bosman et al. 2009). This explains why the respective translations by the King James Bible ('the judgement was set') and the New International Version ('the court was seated') are so different. Although both options are possible, the latter should perhaps be preferred. This is how the Septuagint understood the

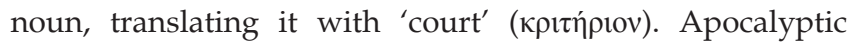
language and imagery permeates this whole pericope. It 
culminates in verse 26 with the court (וְְָינָא) of God judging the fourth beast, taking away his kingdom, and destroying it forever. In this case, the Septuagint translates ו? ְִדינָא not

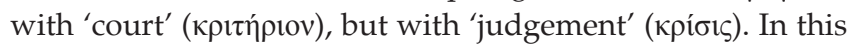
verse, the apocalyptic judgement of God is clearly depicted as taking place via God's heavenly court, which is described with images of an earthly court (cf. Wink 2002:52).

\section{Findings}

During a careful reading of the Old Testament, definite signs of familiarity with the concept of psychostasia were uncovered. The symbolism of weighing someone's inner being was already an obvious metaphor for the act of judgement when the Old Testament came into being. In most (although not all) cases, God is mentioned or implied as the subject of such an act of judgement. The type of judgement differs from one text to another and could include moral, judicial or apocalyptic judgement. The imagery from psychostasia could also, according to the Old Testament, refer to both God's thisworldly and his other-worldly judgement.

That the author(s) and audience of $Q$ were very familiar with courtroom images as metaphors for God's judgement should be accepted without question. Q 12:8-9 takes a very similar scenario to the one in Daniel 7:13 for granted (cf. Kirk 1998:209; cf. also Casey 2009:181; Wink 2002:178). Words like 'judge', 'court', 'judgement', 'courtroom' or 'case' are all entirely absent from this $Q$ pericope. Yet, a heavenly courtroom undeniably forms the interpretive background setting. The author(s) feel(s) no need to explain this. Rather, it is taken for granted that the audience would be able to infer such a setting from the little information given. The repeated use of the preposition $\varepsilon_{\mu} \mu \pi \rho \sigma \theta \varepsilon v$ ('[standing] before'), plus the references to the 'Son of Man' and 'angels', seem to provide sufficient clues that the image of an apocalyptic courtroom is being presupposed (cf. Kirk 1998:209).

Such familiarity with the concept of heavenly courtrooms would strongly suggest that the author(s) of $Q$ also knew about the concept of psychostasia. As a sapiential document, the Sayings Gospel was sure to know formative wisdom sayings from renowned Jewish books like Job and Proverbs very well. The possibility, that the authors of $Q$ were not familiar with the sayings in Proverbs 16:2; 21:2; 24:12 or Job $31: 6$, where images from psychostasia are on the foreground, is slim enough to be omissible. Q 12:8-9 certainly indicates that the Sayings Gospel knew the apocalyptic book of Daniel. It necessarily follows that the imagery of Daniel 5:27 must also have been known to the authors of $Q$.

If it is accepted that the author(s) and people of $\mathrm{Q}$ were familiar with the concept of psychostasia, it stands to reason that the saying in Q 6:37-38 would have evoked the idea of psychostasia. The full implication of this conclusion for our understanding of both, Q 6:37-38 and the Sayings Gospel $Q$ (in its entirety), will be discussed in a third article on this theme. Suffice it to say for now that we end up at more or less the same place we started: With varying degrees of probability, the phrase iv $\alpha \mu \mu \grave{\eta} \kappa \rho \imath \tilde{\eta} \tau \varepsilon$ could justifiably have referenced three different types of judgement: moral, apocalyptic and/or judicial.

\section{Acknowledgements Competing interests}

The author declares that he has no financial or personal relationship(s) that may have inappropriately influenced him in writing this article.

\section{References}

Allison, D.C., 1997, The Jesus tradition in Q, Trinity, Valley Forge, PA. Allison, D.C., 2000, The intertextual Jesus: Scripture in $Q$, Trinity, Harrisburg, PA.

Borg, M.J., 1984, Conflict, holiness, and politics in the teaching of Jesus, Edwin Mellen, Lewiston, NY

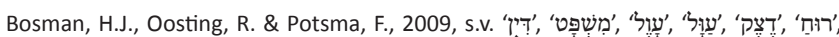

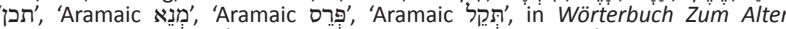
Testament: Hebräisch/Aramäisch-Deutsch Und Hebräisch/Aramäisch-Englisch A Hebrew/Aramaic-English and Hebrew/Aramaic-German Lexicon of the Old Testament, Deutsche Bibelgesellschaft, Stuttgart. (Electronic Edition).

Brandon, S.G.F., 1969, 'The weighing of the soul', in J.M. Kitagawa \& C.H. Long (eds.), Myths and symbols: Studies in honor of Mircea Eliade, pp. 91-110, Chicago University Press, Chicago, IL \& London.

Broyles, J., 2006, Egyptian mythology. Mythology around the world, The Rosen, New York, NY.

Casey, P.M., 2009, The solution to the 'Son of Man' problem, T\&T Clark, London.

Ceresko, A.R., 1999, Introduction to Old Testament wisdom: A spirituality for liberation, Orbis Books, New York, NY.

Crenshaw, J.L. 2010, Old Testament wisdom: An introduction, 3rd edn., Westminster \& John Knox, Louisville, KY.

Edwards, R.A., 1969, 'The eschatological correlative as a Gattung in the New Testament', Zeitschrift für die neutestamentliche Wissenschaft und die Kunde der älteren Kirche 60, 9-20.

Edwards, R.A., 1976, A theology of Q: Eschatology, prophecy, and wisdom, Fortress, Philadelphia, PA. http://dx.doi.org/10.1515/zntw.1969.60.1-2.9

Garnsey, P., 1970, Social status and legal privilege in the Roman Empire, Clarendon, Oxford.

Hoffmann, P., 1995, 'The redaction of Q and the Son of Man', in R.A. Piper (ed.), The Gospel behind the Gospels: Current studies on Q, pp. 159-198, E.J. Brill, Leiden. PMid:7496487

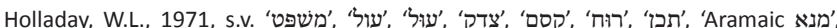
'Aramaic 0 'פ', in, A concise Hebrew and Aramaic lexicon of the Old Testament, $\mathrm{E}$ '. Brill, Leiden, pp. 221, 267, 303, 320, 334-335, 390, 412, 418.

Horsley, R.A., 1995, 'Social conflict in the synoptic Sayings Source Q', in J.S Kloppenborg (ed.), Conflict and invention: Literary, rhetorical and Social Studies on the Sayings Gospel Q, pp. 37-52, Trinity, Valley Forge, PA.

Horsley, R.A., 1996, Archeology, history and society in Galilee: The social context of Jesus and the rabbis, Trinity, Valley Forge, PA. PMCid:PMC1235217

Horsley, R.A. (ed.), 1999, Whoever hears you hears me: Prophets, performance, and tradition in Q Trinity, Harrisburg.

Howes, L., 2012, 'The Sayings Gospel Q within the contexts of the third and renewed quests for the historical Jesus: Wisdom and apocalypticism in the first century', PhD dissertation, Department of New Testament Studies, University of Pretoria.

Kirk, A., 1998, The composition of the Sayings Source: Genre, synchrony, and wisdom redaction in $Q$, Brill, Leiden.

Kloppenborg, J.S., 1987, The formation of Q: Trajectories in ancient wisdom collections, Fortress, Philadelphia, PA.

Louw, J.P. \& Nida, E.A. (eds.), 1993a, Greek-English lexicon of the New Testament based on semantic domains, vol.1 (Domains), United Bible Society, Cape Town

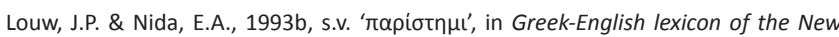
Testament based on semantic domains, United Bible Society, Cape Town, vol. 2 (Indices), p. 189.

Morrison, JV. 1997 'Kerostasia, the dictates of fate, and the will of Zeus in the Iliad', Arethusa 30(2), 276-296. http://dx.doi.org/10.1353/are.1997.0008

Murphy, R.E., 1981, Wisdom literature: Job, Proverbs, Ruth, Canticles, Ecclesiates, and Esther, William B. Eerdmans, Grand Rapids, MI.

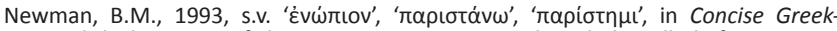
English dictionary of the New Testament, Deutsche Bibelgesellschaft, Stuttgart. (Electronic Edition).

Pearson, B.A., 1976, 'The Pierpont Morgan fragments of a Coptic Enoch Apocryphon', in G.W.E. Nickelsburg (ed.), Studies on the Testament of Abraham, pp. 227-257 Scholars Press, Missoula, MT. (Society of Biblical Literature Septuagint and Cognate Studies, 6). PMid:62767

Perdue, L.G., 1986, 'The wisdom Sayings of Jesus', Forum 2(3), 3-35. 
Pinch, G., 2004, Egyptian mythology: A guide to the gods, goddesses, and traditions of ancient Egypt, Oxford University Press, Oxford.

Piper, R.A., 1989, Wisdom in the Q-Tradition: The aphoristic teachings of Jesus, Cambridge University Press, Cambridge. http://dx.doi.org/10.1017/ CBO9780511520440

Piper, R. A., 1995, 'The language of violence and the aphoristic sayings in Q: A study of Q 6:27-36', in J.S. Kloppenborg (ed.), Conflict and invention: Literary, rhetorical and Social Studies on the Sayings Gospel Q, pp. 53-72, Trinity, Valley Forge, PA.

Rahlfs, A. \& Hanhart, R. (eds.), 2006, Septuaginta, Deutsche Bibelgesellschaft Stuttgart. (SESB Edition). PMCid:PMC1342035

Robinson, J.M., Hoffmann, P. \& Kloppenborg, J.S. (eds.), 2000, The critical edition of $Q$ Fortress, Minneapolis, MN. (Hermeneia Series).

Robbins, V.K., 1998, 'From enthymeme to theology in Luke 11:1-13', in R.P. Thompson \& T.E. Phillips (eds.), Literary Studies in Luke-Acts: Essays in honor of Joseph B. Tyson, pp. 191-214, Mercer University Press, Macon, GA.

Sanders, E.P., 1977, Paul and Palestinian Judaism: A comparison of patterns of religion Fortress, Philadelphia, PA.
Sato, M., 1988, Q und Prophetie: Studien zur Gattungs- und Traditionsgeschichte der Quelle $Q$, JCB Mohr, Tübingen. (Wissenschaftliche Untersuchungen zum Neuen Testament, 2/29).

Schenker, A., 1997, Biblia Hebraica Stuttgartensia, 5th edn., Deutsche Bibelgesellschaft, Stuttgart.

Tuckett, C.M., 1996, Q and the history of early Christianity: Studies on Q, T\&T Clark, Edinburgh.

Van Aarde, A.G., 1994, God-with-us: The dominant perspective in Matthew's story and other essays, University of Pretoria, Pretoria. (HTS Suppl. 5). PMid:7799309.

Wink, W., 2002, The human Being: Jesus and the enigma of the Son of Man, Fortress, Minneapolis, MN.

Winton, A.P., 1990, The Proverbs of Jesus: Issues of history and rhetoric, Sheffield Academic Press, Sheffield.

Youngquist, L.E., 2011, Q 6:37-42: Not judging - The blind leading the blind; The disciple and the teacher; the speck and the beam [Documenta Q], Peeters, Leuven, Paris \& Walpole, MA. 